Journal of Nonformal Education and Community Empowerment

Volume 1 (1): 1-9, Juni 2017

Available at http://journal.unnes.ac.id/sju/index.php/jnfc

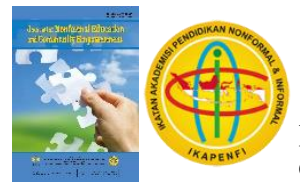

p-ISSN 2549-1539

e-ISSN $2579-4256$

\title{
Manajemen Pelatihan Hantaran dalam Meningkatkan Kecakapan Hidup Warga Belajar di Lembaga Kursus dan Pelatihan
}

\author{
Siti Herlinda ${ }^{\bowtie}$, Sholeh Hidayat, Irwan Djumena
}

\author{
Jurusan Pendidikan Luar Sekolah, FKIP Universitas Sultan Ageng Tirtayasa
}

\begin{tabular}{l} 
Info Artikel \\
\hline Sejarah Artikel: \\
Diterima Maret 2017 \\
Disetujui Mei 2017 \\
Dipublikasikan Juni 2017
\end{tabular}

Keywords:

management training; life skills

\begin{abstract}
Abstrak
Penelitian ini bertujuan mendeskripsikan manajemen pelatihan dalam meningkatkan kecakapan hidup warga belajar, hasil, faktor pendukung dan penghambat. Penelitian ini menggunakan metode kualitatif deskriptif dari hasil observasi, wawancara, dan studi dokumentasi. Subjek penelitian yaitu pengelola, instruktur, dan empat warga belajar. Keabsahan data menggunakan triangulasi sumber, metode dan teori. Analisis data menggunakan tiga tahapan reduksi data, penyajian data, dan simpulan atau verifikasi. Hasil penelitian menunjukkan bahwa manajemen pelatihan sudah berjalan baik, dilihat dari perencanaan, pengorganisasian, pelaksanaan, pengawasan, dan evaluasi. Hasil pelatihan warga belajar dilihat dari tiga aspek yang mengacu ke SKL hantaran serta berkenaan dengan kecakapan hidup yaitu kecakapan personal, kecakapan sosial, kecakapan akademik, dan kecakapan vokasional. Faktor pendukungnya adalah manajerial yang baik, kemauan dan motivasi, sarana dan prasana memadai, instruktur mengajar dengan baik, respon baik warga belajar, serta lingkungan yang bersih. Faktor penghambat adanya perbedaan kemauan dan motivasi setiap warga belajar, jarak tempat pelatihan jauh, dan ruang kelas yang bising.
\end{abstract}

\begin{abstract}
The aim of this study describes the management training in life skills people learn, to find out how the conducting of training in improving life skills people learn, results, supporting and inhibiting factors. This study uses a qualitative method deskripstif from the results of observations, interviews, and documentary studies. This research subject is the manager, instructors, and four learners. Validity of data using triangulation of sources, methods and theories. Data analysis using three stages, data presentation, and conclusion or verification. The results indicate that management training has been going well, judging from the planning, organizing, implementing, monitoring and evaluation. Results of training citizens to learn the views from three aspects that refer to the Competency Standards graduates (SKL) conductivity as well as with respect to life skills namely, personal skills, social skills, academic skills, and vocational skills. The supporting factor are good managerial, willingness and motivation, adequate facilities and infrastructures, teaching instructors were good, good response time learners, as well as a clean environment. Supporting factors are good managerial, willingness and motivation, adequate facilities and infrastructure, well instructed instructors, good citizen learning responses, and a clean environment. Factors inhibit the difference of willingness and motivation of every citizen to learn, distance of far training place, and noisy classrooms.
\end{abstract}

\footnotetext{
Alamat korespondensi:

E-mail: elin.mufc@gmail.com
} 


\section{PENDAHULUAN}

Pembangunan nasional pada hakikatnya adalah pembangunan manusia seutuhnya yang dilakukan secara sengaja untuk meningkatkan potensi yang dimilikinya. Pendidikan memegang peranan penting dalam pembangunan nasional yang mana melalui pendidikan yang baik, akan terlahir manusia Indonesia yang mampu bersaing di era gloobalisasi yang bercirikan tingginya persaingan dalam semua aspek.

Pendidikan adalah proses pembentukan tingkah laku dan kemampuan seseorang yang dapat berguna bagi bangsa dan negara. Pendidikan bertujuan untuk meningkatkan kualitas hidup manusia yang secara teknisoperasional dilakukan melalui pembelajaran. Menurut Undang-Undang No. 20 Tahun 2003 tentang Sistem Pendidikan Nasional menyatakan bahwa jalur pendidikan terdiri dari jalur pendidikan formal, nonformal dan informal.

Pendidikan formal adalah jalur pendidikan yang terstruktur dan berjenjang yang terdiri atas pendidikan dasar, pendidikan menengah, dan pendidikan tinggi. Pendidikan nonformal adalah jalur pendidikan di luar pendidikan formal yang dapat dilaksanakan secara terstruktur dan berjenjang. Pendidikan informal adalah jalur pendidikan keluarga dan lingkungan.

Pendidikan nasional yang berdasarkan Pancasila dan Undang-Undang Dasar Negara Republik Indonesia Tahun 1945 berfungsi mengembangkan kemampuan dan membentuk watak serta peradaban bangsa yang bermartabat dalam rangka mencerdaskan kehidupan bangsa, bertujuan untuk berkembangnya potensi peserta didik agar menjadi manusia yang beriman dan bertaqwa kepada Tuhan Yang Maha Esa, berakhlak mulia, sehat, berilmu, cakap, kreatif, mandiri, dan menjadi warga negara yang demokratis serta bertanggungjawab (UndangUndang No. 20 tahun 2003 Bab II Pasal 3 tentang Sistem Pendidikan Nasional).

Pendidikan yang baik dan bermakna adalah pendidikan yang mampu mengantarkan dan memberdayakan potensi anak didik atau warga belajar sesuai kemampuan yang dimilikinya, bakat, dan minat yang pada akhirnya akan menjadi bekal dimasa depan, bukan semata-mata untuk mengejar target lulus ujian tetapi pendidikan juga harus mampu membekali anak didik dan warga belajar dalam menghadapi problem kehidupan juga dunia kerja. Kesulitan dan tantangan dalam kehidupan manusia, sering memaksa manusia untuk mencari cara yang memungkinkan mereka untuk keluar dari kesulitan yang dialaminya. Masyarakat Indonesia banyak yang tidak melanjutkan pendidikan ke taraf yang memungkinkan dan mereka lalu menggeluti profesi tertentu, menuntut upaya-upaya untuk membantu mereka dalam mewujudkan potensi yang dimilikinya agar dapat bermanfaat bagi pembangunan bangsa.

Terlebih saat ini era globalisasi sedang berlangsung dan Indonesia sedang memasuki era Masyarakat Ekonomi ASEAN (MEA) yang tentu akan semakin sulit dalam persaingan dunia kerja. Indonesia telah meluluskan jutaan siswa, tetapi tidak semuanya mampu melanjutkan pendidikan tinggi atau siap kerja karena terbatasnya skill yang dibutuhkan dunia kerja. Kenyataan yang ada di Indonesia tersebut, maka pendidikan nonformal sangat dibutuhkan.

Pendidikan sebagai salah satu upaya mengantisipasi era global dituntut menyiapkan sumber daya manusia yang kompeten agar mampu bersaing dalam pasar kerja global. Sejalan dengan itu Hidayanto (Anwar, 2012) menjabarkan empat pilar pembelajaran pada era globalisasi menjadi pengetahuan, keterampilan, kemandirian dan kemampuan untuk menyesuaikan dan bekerjasama. Ke empat pilar tersebut, merupakan pilar-pilar belajar yang harus menjadi basis dari setiap pendidikan baik pendidikan formal, maupun pendidikan nonformal dan pendidikan informal dalam penyelenggraannya kegiatan pembelajaran yang bertujuan pada hasil belajar aktual yang diperlukan dalam kehidupan manusia.

Antara pendidikan formal dan pendidikan nonformal telah saling melengkapi. Out put pendidikan formal (sekolah) dari berbagai jenjang yang kurang memiliki keterampilan, 
sebagian dapat dilengkapi dengan keterampilan untuk dapat bekerja pada instansi negeri dan swasta, atau mengembangkan usaha mandiri (wirausaha). Siswa yang putus sekolah dan tidak sempat mengikuti pendidikan formal diberikan kesempatan untuk mengikuti pendidikan nonformal (program pendidikan kecakapan hidup atau life skill) sehingga mampu meningkatkan taraf hidupnya.

Pada tahun 2016 Direktorat Pembinaan Kursus dan Pelatihan, Direktorat Jenderal Pendidikan Anak Usia Dini dan Pendidikan Masyarakat, Kementerian Pendidikan dan Kebudayaan memberikan dana bantuan pemerintah melalui program pendidikan kecakapan kerja (PKK). Pemberian dana PKK tersebut dilatarbelakangi oleh masalah jumlah anak putus sekolah (Drop out) SMK/SMA/MA ditambah lulusan SLTP, SLTA tidak melanjutkan ke pendidikan yang lebih tinggi tahun 2013 sebesar 2.023.222 anak. Penduduk miskin di Indonesia pada semester 2014 sebesar 27,73 juta jiwa atau sebesar $10,95 \%$ dari total penduduk Indonesia, penganggur terbuka di Indonesia pada Agustus 2014 sebesar 7,24 juta jiwa atau 5,94\% dari jumlah angkatan kerja sebesar 121,87 juta jiwa (Direktorat Pembinaan Kursus dan Pelatihan Direktorat Jenderal Pendidikan Anak Usia Dini dan Pendidikan Masyarakat Kementerian Pendidikan dan Kebudayaan, 2016). Kondisi demikian akan memberikan beban tersendiri bagi negara. Dengan terjadinya putus sekolah atau lulus tetapi tidak melanjutkan pendidikan dapat berdampak pada bertambahnya kemiskinan dan pengangguran, selanjutnya akan dapat memicu munculnya permasalahan sosial, sehingga mengakibatkan sumberdaya manusia Indonesia yang kurang mampu menghadapi daya saing bangsa-bangsa lain.

Program PKK adalah program pelayanan pendidikan dan pelatihan berorientasi pada pengembangan keterampilan kerja yang diberikan kepada peserta didik agar memiliki kompetensi di bidang keterampilan tertentu setingkat operator dan teknisi yang bersertifikat kompetensi sehingga dapat dijadikan bekal untuk bekerja pada sektor formal sesuai dengan peluang kerja (Job Opportunities) yang ada.

Program PKK bertujuan untuk memberikan bekal keterampilan kerja bagi warga masyarakat yang menganggur karena tidak memiliki keterampilan yang sesuai kebutuhan dan peluang kerja yang ada, mendorong lembaga pendidikan nonformal untuk memberikan pembekalan bagi masyarakat agar memiliki keterampilan kerja sekaligus mengurangi pengganguran dan kemiskinan dan mendorong masyarakat untuk meningkatkan keterampilan yang dibuktikan dengan sertifikat kompetensi. Dari sekian banyaknya satuan pendidikan nonformal yang menjadi sasaran program PKK, diantara salah satunya adalah lembaga kursus dan pelatihan (LKP).

Lembaga kursus dan pelatihan (LKP) merupakan salah satu bentuk satuan pendidikan nonformal yang diselenggarakan bagi masyarakat yang memerlukan bekal pengetahuan, keterampilan, kecakapan hidup, dan sikap untuk mengembangkan diri, mengembangkan profesi, bekerja, usaha mandiri, atau melanjutkan pendidikan ke jenjang yang lebih tinggi. Menurut pasal 26 Undang-Undang No 20 tahun 2003 tentang Sistem Pendidikan Nasional, pendidikan nonformal berfungsi sebagai pengganti, penambah, atau pelengkap pendidikan formal dalam rangka mendukung pendidikan sepanjang hayat untuk mengembangkan potensi peserta didik dengan penekanan pada penguasaan pengetahuan dan keterampilan fungsional serta pengembangan sikap dan kepribadian professional.

Salah satu bagian dari LKP yang banyak memberikan bekal bagi terbentuknya kualitas sumberdaya manusia yaitu pelatihan. Menurut Edwin B. Flippo (Kamil, 2012:3), "Pelatihan adalah tindakan meningkatkan pengetahuan dan keterampilan seorang pegawai untuk melaksanakan pekerjaan tertentu". Pelatihan secara umum merupakan keseluruhan aktivitas yang dirancang untuk meningkatkan potensi atau kinerja peserta dalam melaksanakan pekerjaan mereka, dan pelatihan menjadi bagian dari pengembangan sumberdaya manusia. 
Dari sekian banyak lembaga kursus dan pelatihan di Kota Serang yang mendapat dana bantuan PKK ini salah satu diantaranya adalah LKP Dilla yang beralamat di Jln. Raya Taktakan Komp. Ciolang Jaya RT 01/02 Kelurahan Panggung Jati Kecamatan Taktakan Serang Banten. Program unggulan dari LKP Dilla yang mendapatkan bantuan PKK adalah pelatihan pembuatan barang hantaran pernikahan level 1. Hantaran pengantin atau pernikahan sering disebut seserahan atau peningset. Adapun isi dan bentuknya tergantung dari adat istiadat, kemampuan pihak pengantin pria dan permintaan pengantin wanita namun pada umumnya berupa barang-barang kebutuhan wanita dan makanan. Barang-barang hantaran diantaranya terdiri dari perangkat sholat, aneka bahan pakaian, seperangkat kosmetik, perlengkapan mandi, sepatu, tas, pakaian dalam, buah-buahan, dan kue. Pada saat ini seiring dengan kemajuan zaman dan teknologi, hantaran pengantin atau pernikahan telah mengalami transformasi tampilan maupun isi, dari yang tadinya hanya sebatas barang bawaan yang dikemas seadanya, menjadi barang yang disajikan lebih menarik tanpa mengurangi makna yang melandasi pemberian hantaran tersebut.

Hasil awal pengamatan peneliti setelah melakukan observasi dan wawancara dengan pengelola LKP Dilla menghasilkan bahwa tidak adanya warga belajar sehingga menyebabkan tidak adanya kegiatan kursus dan pelatihan pada program reguler. Akan tetapi pada saat itu LKP sedang malakukan rekutmen peserta sebagai warga belajar untuk program bantuan PKK. Apabila mengacu pada juknis PKK tahun 2016 mengenai hasil yang diharapkan dari program bantuan ini, yakni "program dapat terselenggara dengan baik dan benar sesuai ketentuan yang ditetapkan dan peserta didik dapat menyelesaikan program pelatihan dengan tuntas, lulus kompetensi dan memperoleh sertifikat kompentensi sebagai bekal untuk bekerja". Pernyataan tersebut mengandung arti bahwa diperlukannya manajemen pelatihan yang dikelola dengan baik, karena hal tersebut menjadi salah satu faktor penentu keberhasilan dan tercapainya tujuan pelatihan.

Menurut Terry (Ruslan, 2008:1), "manajemen merupakan sebuah proses yang khas, yang terdiri dari tindakan-tindakan perencanaan, pengorganisasian, penggiatan dan pengawasan", yang dilakukan untuk menuntun serta mencapai sasaran-sasaran yang telah ditetapkan melalui pemanfaatan sumberdaya manusia dan sumber-sumber lain. Selain empat fungsi manajemen, peneliti menambahkan fungsi lain yakni, evaluasi. Penambahan fungsi evaluasi ini dikarenakan evaluasi merupakan upaya pengumpulan informasi mengenai suatu program, kegiatan, atau proyek. Informasi tersebut berguna bagi pengambilan keputusan, antara lain untuk memperbaiki atau menyempurnakan kegiatan program lanjutan, menghentikan suatu kegiatan (Mugiadi dalam Sudjana, 2009:21). Selain itu evaluasi merupakan kegiatan yang dilakukan untuk menetapkan keberhasilan dan kegagalan suatu program. Berdasarkan permasalahan yang ada, penelitian bertujuan mengkaji manajemen, hasil, faktor pendukung dan penghambat pelatihan dalam meningkatkan kecakapan hidup warga belajar di Lembaga Kursus dan Pelatihan Dilla Kecamatan Taktakan Kota Serang.

\section{METODE}

Penelitian ini menggunakan pendekatan penelitian kualitatif. Menurut (Satori \& Komariah, 2010:25), "Penelitian kualitatif adalah suatu pendekatan penelitian yang mengungkapkan situasi sosial tertentu dengan mendeskripsikan kenyataan secara benar, dibentuk oleh kata-kata berdasarkan teknik pengumpulan dan analisis data yang relevan yang diperoleh dari situasi yang alamiah". Selain itu metode yang digunakan dalam penelitian ini adalah metode deskriptif. Menurut Syaodih (2010:72), "Metode deskriptif adalah bentuk penelitian yang ditujukan untuk mendeskripsikan atau menggambarkan fenomena-fenomena yang ada, baik fenomena yang bersifat alamiah ataupun rekayasa manusia". Dengan menggunakan metode deskriptif, peneliti akan menggambarkan dan 
mendeskripsikan tentang manajemen Lembaga Kursus dan Pelatihan (LKP) Dilla Kecamatan Taktakan Kota Serang.

Sumber data dalam penelitian ini dibagi menjadi dua aspek yaitu sumber data primer dan sumber data sekunder. Jumlah sumber data dalam penelitian ini adalah enam orang, yang terdiri Pengelola LKP, Instruktur pelatihan hantaran dan empat warga belajar pelatihan hantaran. Pada data primer peneliti menemukan data secara langsung pada sumbernya sedangkan pada data sekunder peneliti menemukan data dengan secara tidak langsung ataupun berupa gambar, buku-buku maupun data-data yang berhubungan dengan penelitian.

Langkah-langkah pengumpulan data dalam penelitian ini dilakukan dengan tiga tahap yaitu tahap orientasi yang bertujuan untuk memperoleh gambaran yang tepat tentang latar penelitian. Pada tahap ini dilakukan kegiatan pra survei. Tahap kedua yaitu eksplorasi, pada tahap ini dilakukan penelitian yang sebenarnya yaitu dilakukan pengumpulan data terhadap sampel penelitian yang berkaitan dengan fokus dan tujuan penelitian. Tahap ke tiga yaitu member check atau kegiatan pengecekan data pada subyek atau informan membuktikan validitas data yang diperoleh atau bisa disebut dengan perbaikan baik dari segi bahasa maupun sistematika.

Selain itu, peneliti juga menggunakan teknik dan pedoman pengumpulan data. Hal ini sebagai langkah yang paling utama dalam penelitian untuk mendapatkan data dengan menggunakan teknik wawancara, observasi dan dokumentasi.

Kisi-kisi dalam penelitian ini terbagi menjadi tiga berdasarkan pada fokus penelitian. Kisi-kisi yang pertama adalah manajemen pelatihan hantaran, untuk mengetahui manajemen pelatihan hantaran yaitu menggunakan indikator perencanaan, pengorganisasian, pelaksanaan, pengawasan dan evaluasi. Kisi-kisi yang kedua yaitu hasil pelatihan dalam meningkatkan kecakapan hidup, untuk mengetahui hasil pelatihan dalam meningkatkan kecakapan hidup menggunakan indikator keberhasilan pelatihan dan kecakapan hidup (kecakapan personal, kecakapan sosial dan kecakapan vokasional). Kisi-kisi yang ke tiga adalah faktor pendukung dan faktor penghambat, untuk mengetahui faktor-faktor tersebut yaitu melalui indikator faktor internal dan faktor eksternal.

Dalam penelitian ini, untuk mendapatkan suatu kesimpulan yang benar atau valid yaitu menggunakan teknik analisis data. Dalam proses analisis data memiliki tiga tahapan yaitu reduksi data, penyajian data, dan simpulan atau verifikasi. Dalam reduksi data peneliti memfokuskan pada hal-hal penting yang berada pada catatan lapangan untuk di rangkum atau disederhanakan. Setelah mereduksi data, dilanjutkan pada penyajian data yaitu penyajian informasi dalam bentuk uraian atau naratif untuk memudahkan memahami apa yang terjadi dalam penelitian. Simpulan atau verifikasi pada proses ini dilakukan uji kebenaran pada setiap data yang muncul dari data yang diperoleh.

\section{HASIL DAN PEMBAHASAN}

\section{Manajemen Pelatihan Hantaran dalam Meningkatkan Kecakapan Hidup Warga Belajar}

Berdasarkan hasil wawancara yang dilakukan terhadap pengelola LKP dan instruktur bahwa ada beberapa tahapan dalam manajemen pelatihan meliputi perencanaan, pengorganisasian, pelaksanaan, pengawasan dan evaluasi. Perencanaan terdapat beberapa tahapan dalam menyusun perencanaan yaitu mengidentifkasi kebutuhan, penyusunan tujuan pelatihan, menentukan instuktur, rekutmen warga belajar, menentukan kurikulum, sumber belajar, metode dan waktu pelatihan. Setiap akan merumuskan kegiatan pelatihan, pihak LKP dilla mengidentifkasi dan menganalisis kebutuhan pelatihan terlebih dahulu. Dalam proses mengidentifikasi, dilakukan dengan teliti sehingga diperoleh data dan informasi yang didapat bisa dijadikan tolak ukur suatu pelatihan dapat dilaksanakan. Setelah pengelola LKP melakukan identifikasi kebutuhan, barulah disusun tujuan pelatihan, menentukan sumber belajar, metode dan waktu pelatihan dilakukan oleh pengelola pelatihan. Kurikulum pada 
pelatihan ini menggunakan kurikulum berbasis kompetensi (KBK) yang mengacu pada Standar kompetensi lulusan (SKL). Selain itu sumber belajar menggunakan modul yang didapat dari pemerintah. Metode pelatihan yang digunakan pada proses pembelajaran adalah metode ceramah, demonstrasi, tanya jawab dan penugasan. Tahap selanjutnya adalah menentukan instruktur dalam pelatihan hantaran dan rekutmen warga belajar. Setelah semua tahap dilakukan, selanjutnya dirumuskan dalam bentuk proposal. Proposal tersebut berguna sebagai pengajuan permohonan dana bantuan PKK pada pelatihan hantaran.

Perencanaan (planning), menurut Bintoro Tjokroaminato (Badrudin, 2014:54), "Perencanaan adalah proses mempersiapkan kegiatan-kegiatan secara sistematis yang akan dilakukan untuk mencapai tujuan tertentu". Pada hakikatnya perencanaan adalah proses pengambilan keputusan atas sejumlah alternatif (pilihan) mengenai sasaran dan cara-cara yang akan dilaksanakan di masa yang akan datang guna mencapai tujuan yang dikehendaki serta pemantuan dan penilaiannya atas hasil pelaksanaannya, yang dilakukan secara sistematis dan berkesinambungan.

Pengorganisasian, berdasarkan hasil wawancara yang dilakukan terhadap pengelola LKP bahwa tahapan pada pengorganisasian adalah menentukan dan memberikan tugas kepada pihak-pihak yang nantinya terlibat saat proses pelaksanaan pelatihan hantaran. Tugas dari pengelola LKP dalam kaitannya dengan proses pelaksanaan adalah memantau kegiatan pelatihan. Selain itu pengelola juga bertugas sebagai instruktur pengganti apabila instruktur utama tidak bisa hadir. Pengorganisasian (organizing), menurut Terry (Hasibuan, 2011:119), "Pengorganisasian adalah tindakan mengusahakan hubungan-hubungan kelakuan yang efektif antara orang-orang", sehingga dapat bekerja sama secara efisien dan dengan demikian memperoleh kepuasan pribadi dalam hal melaksanakan tugas-tugas tertentu dalam kondisi lingkungan tertentu guna mencapai tujuan atau sasaran teretentu.
Pelaksanaan (actuating) merupakan penerapan dari perencanaan yang telah disusun sebelumnya dan pelaksanaan merupakan salah satu faktor yang menentukan keberhasilan dari suatu program atau kegiatan. Pelaksanaan berdasarkan hasil wawancara yang dilakukan terhadap pengelola LKP dan instruktur bahwa pelaksanaan merupakan proses pembelajaran pelatihan dari adanya realiasasi perencanaan dan pengorganisasian. jumlah warga belajar yang mengikuti pelatihan hantaran ini sebanyak 20 orang. Pelatihan hantaran dilaksanakan di LKP dilla yang beralamat di Jln Raya Taktakan Komp. Ciloang Jaya Rt 02/01 Kelurahan Panggung Jati Kecamatan Taktakan Kota Serang Provinsi Banten dan waktu pelaksanaan dilakukan pada hari senin sampai dengan hari kamis, dengan durasi disetiap pertemuan adalah selama $3 \mathrm{jam}$. Pelatihan ini dimulai pada tanggal 5 Oktober 2016 hingga 21 November 2016. Adapun perbandingan teori sebanyak $30 \%$ dan $70 \%$ praktik. Penggunaan alat dan bahan disesuaikan dengan jenis materi yang disampaikan karena setiap materi membutuhkan alat dan bahan yang berbeda-beda.

Pengawasan (controlling) menurut Suarli \& Yanyan (2010:16), "Pengawasan adalah suatu proses untuk mengetahui apakah pelaksanaan kegiatan atau pekerjaan sesuai dengan rencana, pedoman, ketentuan, kebijakan, tujuan dan sasaran yang sudah ditentukan sebelumnya". Pengawasan berdasarkan hasil wawancara yang dilakukan terhadap pengelola LKP dan instruktur bahwa kegiatan pengawasan dilakukan agar terpantaunya proses pembelajaran yang baik sesuai yang diharapkan. Kegiatan pengawasan ini dilakukan oleh pengelola dan pihak luar yakni UPTD, beberapa hal yang diawasi adalah proses pembelajarannya.

Evaluasi, berdasarkan hasil wawancara yang dilakukan terhadap pengelola LKP bahwa kegiatan evaluasi hasil belajar dilaksanakan melalui evaluasi perkembangan hasil belajar pada tiap tahapan kegiatan pembelajaran dan evaluasi akhir melalui uji kompetensi. Penilaian terhadap warga belajar dengan tiga aspek kemampuan warga belajar yakni, aspek 
pengetahuan (kognitif), sikap kerja (afektif) dan keterampilan (psikomotor) yang diaplikasikan ke dalam kategori kecakapan hidup yaitu kecakapan personal, sosial dan kecakapan vokasional. Evaluasi (evaluation) atau penilaian adalah fungsi kelima dalam manajemen, khususnya pendidikan luar sekolah. Ralph Tyler (Sudjana, 2008:19), "Penilaian dilakukan terhadap seluruh atau sebagian komponen program serta terhadap pelaksanaan program Pendidikan". Dengan adanya penilaian kita mampu mengukur tingkat keberhasilan kita dalam pencapaian tujuan.

Manajemen pelatihan hantaran merupakan suatu kegiatan untuk meningkatkan kemampuan dan keterampilan warga belajar. Proses ini dimulai dari perencanaan, pengorganisasian, pelaksanaan, pengawasan dan evaluasi. Oleh karenanya akan tercapai tujuan yang telah direncanakan sebelumnya dengan merencanakan kegiatan pelatihan yang dilakukan oleh pengelola LKP. Hal ini sejalan dengan apa yang dikatakan oleh Terry (Ruslan, 2008:1) mengemukakan bahwa "Manajemen merupakan sebuah proses yang khas, yang terdiri dari tindakan-tindakan: perencanaan, pengorganisasian, penggiatan dan pengawasan", yang dilakukan untuk menentukan serta mencapai sasaran-sasaran yang telah ditetapkan melalui pemanfaatan sumber daya manusia dan sumber-sumber lain.

\section{Hasil Pelatihan}

Berdasarkan hasil wawancara yang dilakukan oleh pengelola, instruktur dan empat orang warga belajar, hasil pelatihan hantaran terdiri dari hasil yang dicapai. Hasil tersebut mencakup tiga aspek kemampuan pada warga belajar yang berkenaan dengan kecakapan hidup warga belajar. Tiga aspek tersebut yakni pengetahuan, sikap kerja, dan keterampilan yang mengacu pada standar kompetensi lulusan hantaran dan yang berkenaan juga dengan kecakapan hidup. Adapun peningkatan kecakapan hidup yaitu:

a) Kecakapan personal termasuk kedalam kemampuan dalam hal sikap kerja warga belajar. Setelah warga belajar selesai mengikuti pelatihan maka kecakapan personal yang dimiliki peserta pelatihan yaitu saling membantu. Saat proses pembelajaran warga belajar saling membantu apabila ada yang tidak membawa peralatan atau bahan, dan membantu apabila ada yang belum bisa atau belum paham materi. Hal ini sebagai salah satu perwujudan dari sikap diri sebagai makhluk Tuhan Yang Maha Esa yang harus saling membantu.

b) Kecakapan sosial termasuk kedalam kemampuan dalam hal sikap kerja warga belajar. Setelah warga belajar selesai mengikuti pelatihan maka kecakapan sosial yang dimiliki peserta pelatihan yaitu kemampuan untuk berinteraksi, berkomunikasi dengan teman sejawat, menjalin kerjasama.

c) Kecakapan vokasional, setelah warga belajar selesai mengikuti pelatihan maka kecakapan vokasional yang dimiliki peserta pelatihan yaitu mempunyai keterampilan hantaran. Dengan keterampilan bidang hantaran yang dimiliki, warga belajar bisa mempunyai usaha sampingan dengan membuka dan menerima pesanan membuat dan mendekorasi hantaran.

Hasil pelatihan hantaran berupa tiga aspek kemampuan pada warga belajar yang mengacu pada standar kompetensi lulusan yang meliputi pengetahuan, sikap kerja dan keterampilan sekaligus berkenaan dengan meningkatkan kecakapan hidup warga belajar. Pelatihan berbasis hantaran meningkatkan kecakapan hidup, menekankan pembelajaran ke arah kecakapan hidup yang dimiliki oleh warga belajar untuk berani menghadapi problema hidup dan kehidupan dengan wajar tanpa merasa tertekan. Departemen pendidikan nasional dalam (Anwar, 2012:28) membagi empat jenis kecakapan hidup yaitu "Kecakapan personal (personal skills), kecakapan sosial (social skills), kecakapan akademik (academic skills), kecakapan vakasional (vocational skills)".

Pelatihan hantaran yang diselenggarakan di LKP Dilla dapat meningkatkan tiga jenis kecakapan hidup. Kecakapan personal terlalu sempit definisinya karena hanya difokuskan 
pada pengenalan diri (self awareness). Padahal kecakapan personal sangat luas dimensinya. Dalam pelatihan hantaran ini kecakapan personal termasuk kedalam kemampuan dalam hal sikap kerja warga belajar. Kecakapan sosial adalah kemampuan untuk berhubungan dan bekerja sama dengan orang lain. Dalam penelitian ini kecakapan sosial termasuk kedalam kemampuan dalam hal sikap kerja warga belajar. Setelah warga belajar selesai mengikuti pelatihan maka kecakapan sosial yang dimiliki peserta pelatihan yaitu kemampuan untuk berinteraksi, berkomunikasi dengan teman sejawat. Kecakapan vokasional, setelah warga belajar selesai mengikuti pelatihan maka kecakapan vokasional yang dimiliki peserta pelatihan yaitu mempunyai keterampilan hantaran.

\section{Faktor Pendukung dan Faktor Penghambat}

Berdasarkan hasil wawancara dengan pengelola, instruktur dan empat orang warga belajar, pelatihan hantaran di LKP Dilla diketahui mengenai pernyataan mereka terhadap faktor pendukung dan faktor penghambat manajemen pelatihan yang dibagi menjadi faktor internal dan eksternal.

\section{Faktor internal}

Faktor yang mendukung dalam manajemen pelatihan adalah manajerial yang baik yang dilakukan pengelola beserta stafstafnya, adanya kemauan dan motivasi warga belajar untuk mengikuti pelatihan, sarana dan prasana yang memadai, cara mengajar instruktur yang baik, respon yang baik warga belajar saat penyampaian materi, serta lingkungan yang bersih sehingga menunjang kelancaran dalam proses pembelajaran

Terlaksananya pelatihan hantaran menjadi tanda adanya hubungan dan kerja sama yang baik dengan pihak-pihak terkait pelatihan. Karena tahap pelaksanaan atau proses pembelajaran merupakan realisasi dari tahaptahap sebelumnya. Adanya kemauan atau motivasi untuk ikut pelatihan hantaran karena warga belajar merasa tertarik dan sadar akan pentingnya mempunyai pengetahuan dan keterampilan, khususnya dibidang hantaran dalam dunia kerja dibutuhkan. Cara mengajar instuktur saat proses pembelajaran sudah sangat baik. Cara penyampaiannya yang cukup jelas dan mudah dimengerti selain itu instuktur sabar dan mau mengulangi materi apabila ada warga belajar yang belum mengerti mengenai materi yang disampaikan ataupun yang sudah disampaikan hal ini direspon sangat baik oleh warga belajar karena dengan begitu banyak warga belajar yang terlihat antusias ketika mengikuti proses pembelajaran.

Sedangkan faktor penghambat kemauan dan motivasi dari setiap warga belajar yang berbeda-berbeda untuk mengikuti proses pembelajaran. Terdapat beberapa kegiatan yang mengalami penurunan peserta, ada saja warga belajar yang terlambat mengikuti proses pembelajaran karena memiliki kesibukan lain dan saat penyampaian materi ada saja warga belajar yang tidak mendengarkan, mengobrol maupun bermain handphone.

\section{Faktor eksternal}

Berdasarkan hasil wawancara terhadap pengelola LKP, instruktur dan empat orang warga belajar pelatihan hantaran, faktor pendukung eksternal meliputi Sarana dan prasarana serta lingkungan. Faktor pendukung mengenai kelengkapan sarana dan prasana yang ada di LKP Dilla dalam pelatihan hantaran cukup memadai untuk menunjang pelatihan hantaran. Selain itu lingkungan menjadi pendukung proses pelatihan dengan adanya lahan parkir dan lokasi LKP yang strategis karena dekat dengan jalan raya.

Sedangkan faktor penghambat dalam jarak antara tempat pelatihan dengan rumah tutor dan sebagian warga belajar yang jauh mengakibatkan terlambatnya dalam memberikan materi sehingga pelaksanaan pelatihan kurang efektif. Selain itu kondisi ruang kelas yang berada di samping jalan raya mengakibatkan sering terdengar suara bising yang berasal dari kendaraan yang lewat. Hal ini cukup menggangu sebagian warga belajar saat penyampaian materi oleh instruktur. 


\section{SIMPULAN}

Manajemen pelatihan hantaran dalam meningkatkan kecakapan hidup warga belajar di LKP Dilla dilakukan melalui lima tahapan yaitu perencanaan, pengorganisasian, pelaksanaan, pengawasan dan evaluasi. Hasil pelatihan hantaran berupa tiga aspek yang meliputi pengetahuan, sikap kerja dan keterampilan yang mengacu pada standar kompetensi lulusan sekaligus berkenaan dalam meningkatkan kecakapan hidup warga belajar. Pelatihan hantaran dapat meningkatkan kecakapan hidup warga belajar mencakup kecakapan personal yaitu saling membantu. Kecakapan sosial yaitu kemampuan untuk berinteraksi, berkomunikasi dengan teman sejawat. Sedangkan kecakapan vakasional yaitu mempunyai keterampilan hantaran.

Faktor yang mendukung manajemen pelatihan mencakup manajerial yang baik yang dilakukan pengelola beserta staf-stafnya, adanya kemauan dan motivasi, sarana dan prasana yang memadai, cara mengajar instruktur yang baik, respon baik warga belajar saat penyampaian materi, serta lingkungan yang bersih. Faktor yang menghambat manajemen pelatihan adanya perbedaan kemauan dan motivasi, cara mengajar instruktur serta respon warga belajar saat penyampaian materi. Jarak antara tempat pelatihan dengan rumah instruktur dan sebagian warga belajar yang lumayan jauh. Selain itu kondisi ruang kelas yang berada di samping jalan raya mengakibatkan sering terdengar suara bising yang berasal dari kendaraan yang lewat.

Implementasi manajemen hantaran tidak hanya untuk penyelenggaraan pelatihan hantaran saja, tetapi dapat digunakan untuk keseluruhan program pelatihan yang diselenggarakan oleh Lembaga Kursus dan Pelatihan Dilla. Hasil pelatihan oleh warga belajar setelah mengikuti proses pelatihan perlu adanya tindakan lanjut berupa pembinaan ataupun pengarahan dengan dibantu oleh pihakpihak terkait supaya ilmu dan keterampilan yang dimiliki oleh warga belajar dapat bisa diterapkan. Perlu adanya pemberian motivasi kepada warga belajar lebih rutin dilakukan agar dalam pelaksanaannya baik secara teori maupun praktik berjalan sesuai dengan rencana yang telah ditetapkan dan juga warga belajar hendaknya lebih aktif lagi dalam mengikuti pembelajaran baik secara teori maupun praktik demi mendapatkan hasil, baik dari segi pengetahuan maupun keterampilan serta dapat menerapkan secara mandiri.

\section{DAFTAR PUSTAKA}

Anwar. (2012). Pendidikan kecakapan hidup (life skill education). Bandung: Alfabeta.

Badrudin. (2014). Dasar-Dasar Manajamen. Bandung: Alfabeta.

Direktorat Pembinaan Kursus dan Pelatihan Direktorat Jenderal Pendidikan Anak Usia Dini dan Pendidikan Masyarakat Kementerian Pendidikan dan Kebudayaan. (2016). Petunjuk teknis program pendidikan kecakapan kerja (PKK). Jakarta: Direktorat Pembinaan Kursus dan Pelatihan. Retrieved from http://www.infokursus.net/download/Ju knis_PKK_2016.pdf

Hasibuan, M. (2011). Manajemen: Dasar, Pengertian, dan Masalah. Jakarta: Bumi Aksara.

Kamil, M. (2012). Model pendidikan dan pelatihan (konsep dan aplikasi). Bandung: Alfabeta.

Ruslan, R. (2008). Manajemen Public Relation \& Media Komunikasi: Konsep dan Aplikasi. Jakarta: PT Raja Grafindo Persada.

Satori, D., \& Komariah, A. (2010). Metodologi Penelitian Kualitatif. Bandung: Alfabeta.

Suarli, \& Yanyan. (2010). Manajemen Keperawatan: dengan Pendekatan Praktis. Jakarta: Erlangga.

Sudjana, D. (2008). Evaluasi Program Pendididkan Luar Sekolah. Bandung: PT Remaja Rosdakarya.

Sudjana, N. (2009). Penilaian Hasil Proses Belajar Mengajar. Bandung: PT Remaja Rosdakarya.

Syaodih, N. (2010). Metode Penelitian Pendidikan. Bandung: PT Remaja Rosdakarya. 